\title{
壁縦筋の定着方法の異なるCES 造連層耐震壁の非線形 FEM 解析 NON-LINEAR FEM ANALYSIS FOR CES SHEAR WALLS OF DIFFERENT ANCHORAGE CONDITION OF LONGITUDINAL WALL REINFORCING BARS
}

\author{
鈴木 卓*, 松井智哉**, 倉本 洋*** \\ Suguru SUZUKI, Tomoya MATSUI and Hiroshi KURAMOTO
}

\begin{abstract}
A two-dimensional non-linear FEM analysis for CES shear walls was conducted to verify the validity of analytical modeling assumed and constitutive modeling for materials used. Internal stress conditions in the shear walls were also investigated through the FEM analysis. Analytical results for the shear versus drift relationships of the shear walls showed good agreements with the experimental results. It was also indicated through the analysis that the difference of anchoring method of longitudinal wall reinforcing bars to boundary beams affects little on the internal stress conditions and overall behavior of the shear walls.
\end{abstract}

Keywords: CES Shear walls, Static loading test, FRC, Shear span ratio, Anchorage condition, FEM analysis CES 而震壁，静的載荷実験，䋊維補強コンクリート，せん断スパン比，定着状態，FEM解析

\section{1. はじめに}

鋼コンクリート合成構造 (Concrete Encased Steel : 以下, CES 構 造）は鉄骨と繊維補強コンクリート（以下，FRC）のみからなる合 成構造であり, SRC 構造と比べて鉄筋工事がないため施工性および コスト面で有利な構造形式となっている。これまでに, 柱, 柱梁接 合部および 2 層 2 スパンフレームを対象とした実験的研究 1)-3)を行 い, SRC 構造と同等以上の優れた復元力特性および安定した履歴特 性を示し，高い耐震性能を有することが確認されている。

一方，建築物の主要耐震部材のひとつである耐震壁は, CES 構造 においても剛性および強度を確保する上で有効である。しかし, 柱 および梁に充腹形鉄骨が内蔵されている CES 構造では, SRC 構造と 同様に, 壁筋の配笳が困難であることは想像に難くない。最近では, $\mathrm{SRC}$ 耐震壁について周辺骨組と壁板との接合部のディテールに関 する研究 ${ }^{4)}$ も行われてきており, CES 耐震壁の開発にあたっては周 辺架構と壁板との接合部の施工性の改善も重要な課題である。

このような背景から, 筆者等は CES 造周辺架構と壁板との定着を 簡略化した CES 造耐震壁の構造性能を明らかにするために静的加 力実験を実施し，壁縦筋の定着を省略したものと同等以上の耐力性 能および変形性能を有することを示した ${ }^{5)}$ 。一方で, 既往の終局強 度式 ${ }^{6}$ による耐力算定結果では実験值を過小評価する傾向が認めら れ, 耐力評価精度を向上させるためには耐震壁の応力伝達機構に基 づいた評価法を開発する必要があると考えられる。

本研究では, CES 構造の構造性能評価法の開発に資する基礎資料 を整備することを目的として文献 5)に示した実験を対象に FEM 解 析を実施し, 履歷特性, 破壊状況および変形性能から解析のモデル
化および材料構成則の妥当性について検討する。また，内部応力状 態から壁縦筋の定着の有無による応力伝達メカニズムの差異を明ら かにする。

\section{2. 解析対象実験の概要 \\ 2.1 試験体}

解析対象試験体は，中高層壁フレーム建築物における連層耐震壁 の下部 2 層を想定した実大の約 $1 / 3$ 縮尺のもの 4 体である。試験体 の形状および配筋を図 1 および図 2 に示す。また，表 1 に試験体の 部材断面詳細を示す。耐震壁は階高が $1,000 \mathrm{~mm}$, 柱中心間距離が $1,800 \mathrm{~mm}$ および壁厚が $100 \mathrm{~mm}$ であり, 側柱断面が $250 \mathrm{~mm}$ 角である。 また,壁梁の幅およびせいはそれぞれ $200 \mathrm{~mm}$ および $250 \mathrm{~mm}$ である。 本実験では壁縦筋の定着状態が構造特性に及ぼす影響を確認するこ

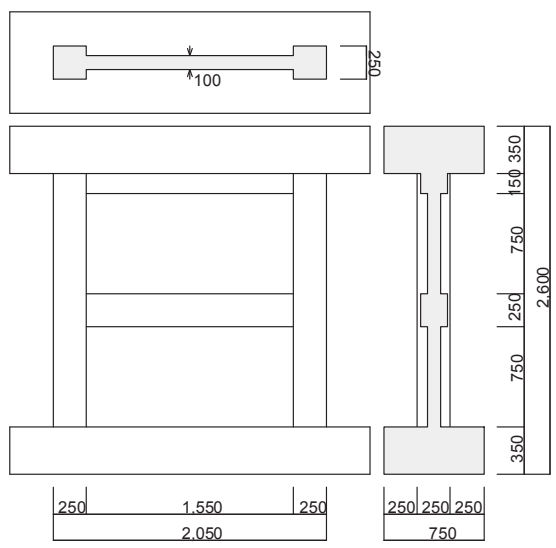

図 1 試験体形状
* 大阪大学大学院工学研究科地球総合工学専攻 大学院生

** 豊橋技術科学大学大学院工学研究科 建築・都市システム学系 助教・博士 (工学)

*** 大阪大学大学院工学研究科地球総合工学専攻 教授・博士 (工学)
Graduate School, Div. of Global Architectural Engineering, Osaka Univ., M. Eng. Assistant Prof., Dept. of Architecture \& Civil Engineering, Graduate Engineering, TUT, Dr. Eng.

Prof., Div. of Global Architecture, Graduate Engineering, Osaka Univ., Dr. Eng. 
とを主たる目的としているため壁横筋は側柱の内蔵鉄骨ウェブに溶 接している。

実験変数は表 2 に示すように壁縦筋の定着の有無とせん断スパン 比である。図 2 に示すように試験体 CWAS および CWAF では, 壁 縦筋を梁内およびスタブに定着せず壁板内でフックを設けている。

一方, 試験体 CWBS および CWBF では, 壁縦筋を梁内およびス夕 ブに定着させている。また, 試験体 CWAS および CWBS ではせん 断スパン比 $(\mathrm{M} /(\mathrm{Q} ・ \mathrm{D}), \mathrm{D}$ : 壁の全せい) を 1.1 とし, 試験体 $\mathrm{CWAF}$ および CWBF では 1.65 として, それぞれせん断破壊先行型および 曲げ降伏先行型となるように計画した。

表 3 に FRC の材料特性を, 表 4 に鉄骨および鉄筋の材料特性をそ れぞれ示す。上下スタブを除く試験体の柱, 梁および壁板のコンク リートに FRC を使用しており, 呼び強度 $30 \mathrm{MPa}$ である。コンクリ 一トは試験体を立てた状態で打設し, 下スタブ, 1 層（1 層梁上端ま で), 2 層（上スタブ下端まで）, および上スタブの 4 回に分けて行 った。

\section{2 載荷方法}

試験体設置状況を写真 1 に示寸。載荷は, 反力壁に取り付けたオ イルジャッキ $(2,000 \mathrm{kN})$ によって, 変位制御で水平方向の正負繰り 返し載荷を行い, さらに, 左右の鉛直オイルジャッキ (各 $2,000 \mathrm{kN})$ により, $1,260 \mathrm{kN}$ の一定軸力（柱軸力比 $\mathrm{N} / \mathrm{N}_{0}=0.2, \mathrm{~N}_{0}$ : 鉄骨を含む 軸圧縮耐力）を試験体頂部に作用させると同時に, せん断スパン比 が 1.1 もしくは 1.65 となるように作用せん断力に対応させて当該鉛 直ジャッキを制御することによって試験体頂部に付加モーメントを 作用させた。実験では試験体頂部の水平変位 $(\delta)$ を計測位置の高さ $(\mathrm{H}=2,050 \mathrm{~mm})$ で除した部材角 $\mathrm{R}=\delta / \mathrm{H}$ を制御変位とした。

\section{3 実験結果}

図 3 に試験体のせん断力一部材角関係を示す。また, 同図には曲 げ終局強度の算定結果も併せて示している。曲げ終局強度式 $\mathrm{Q}_{\mathrm{mu}}$ (式 （1）は文献 6)による算定式から側柱鉄筋の項を除いた式を用いた。 なお, 試験体 CWAS および CWAF の曲げ終局強度の算定においては 壁縦筋を省略して計算した。

$$
Q_{m u}=\left(\frac{N_{U}}{2}+{ }_{s C S} A_{s} \sigma_{Y}+\frac{m W}{2} A{ }_{W} \sigma_{Y}\right)_{W} l / h_{W}
$$

せん断破壊先行型試験体 CWAS と CWBS の最大耐力はほぼ等し いが，壁縦筋を定着していない試験体 CWAS は徐々に耐力が低下し

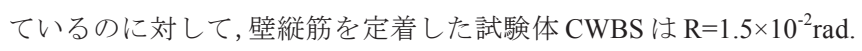
のサイクルにおいて急激に耐力が低下している。試験体 CWBS は, 1 層壁板全体に亘って斜めにせん断破壞が生じている。一方で, 試 験体 CWAS は $\mathrm{R}=0.75 \times 10^{-2} \mathrm{rad}$.のサイクルから 1 層壁板上隅角部の損 傷が目立ち始め, 図 4 に示寸ように $\mathrm{R}=1.0 \times 10^{-2} \mathrm{rad}$.のサイクルで 1 層 梁と 1 層壁板境界にずれが増大していることが確認され（ずれの計 測位置は図 12 を参照), 最終的に 1 層壁板上隅角部に損傷が集中し た。すなわち, 試験体 CWAS では, 最大耐力以降, 鉄筋の定着のな い梁下でずれが生じることにより, 壁板隅角部に局所的な損傷は生 じたものの, 全体的に壁板のせん断変形が緩和され, せん断破壊が 生じず, 試験体 CWBS よりも勒性が向上したものと考えられる。

曲げ降伏先行型試験体においても壁縦筋の定着の有無に拘わらず 最大耐力は同程度であるが, 変形能力に若干の違いが見られる。両 試験体とも $\mathrm{R}=2.0 \times 10^{-2} \mathrm{rad}$.のサイクルから, 側柱および壁板の下隅角

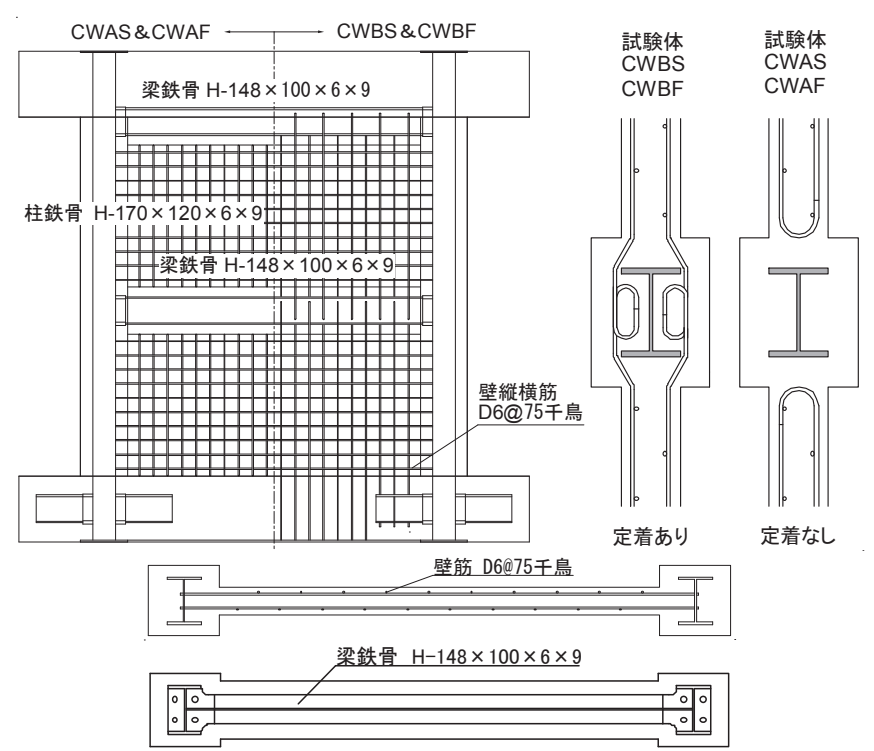

図 2 試験体配筋図

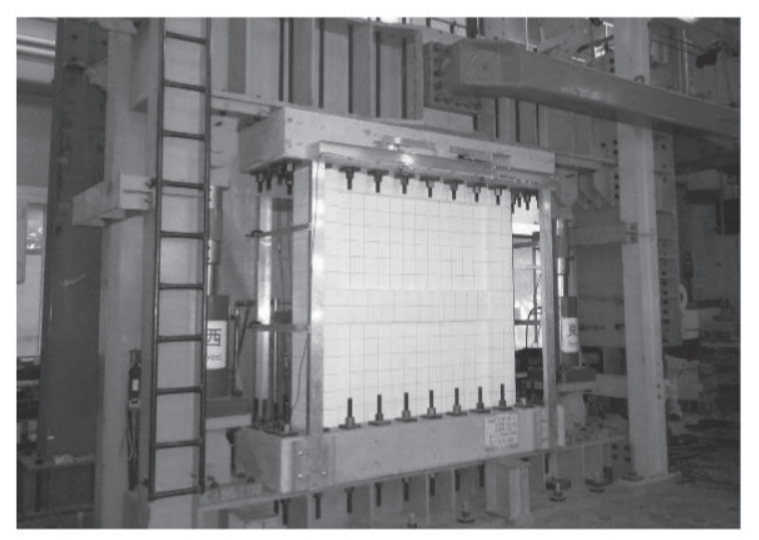

写真 1 試験体設置状況

表 1 部材断面詳細

\begin{tabular}{|c|c|c|}
\hline \multirow{2}{*}{ 柱 } & $B \times D$ & $250 \times 250(\mathrm{~mm})$ \\
\hline & 鉄骨 & $\mathrm{H}-170 \times 120 \times 6 \times 9\left({ }_{s} \mathrm{p}=4.9 \%\right)$ \\
\hline \multirow{2}{*}{ 梁 } & $B \times D$ & $200 \times 250(\mathrm{~mm})$ \\
\hline & 鉄骨 & $\mathrm{H}-148 \times 100 \times 6 \times 9\left({ }_{s} \mathrm{p}=5.2 \%\right)$ \\
\hline \multirow{3}{*}{ 壁 } & 壁厚 & $100(\mathrm{~mm})$ \\
\hline & 縦筋 & D6@75 千鳥 ( \\
\hline & 横筋 & D6@75 千鳥 ( \\
\hline
\end{tabular}

表 2 実験変数

\begin{tabular}{c||c|c|c|c}
\hline 実験変数 & CWAS & CWBS & CWAF & CWBF \\
\hline \hline せん断スパン比 & 1.1 & 1.1 & 1.65 & 1.65 \\
\hline 壁縦筋接合方法 & 定着なし & 定着あり & 定着なし & 定着あり \\
\hline \multicolumn{7}{c}{ 表 3 FRC の材料特性 }
\end{tabular}

\begin{tabular}{c|c||c|c|c|c}
\hline \multicolumn{2}{c||}{} & $\begin{array}{c}\text { 圧縮強度 } \\
(\mathrm{MPa})\end{array}$ & $\begin{array}{c}\text { ヤング係数 } \\
(\mathrm{GPa})\end{array}$ & $\begin{array}{c}\text { 圧縮強度時 } \\
\text { ひずみ }(\mu)\end{array}$ & $\begin{array}{c}\text { 引張強度* } \\
(\mathrm{MPa})\end{array}$ \\
\hline \hline \multirow{2}{*}{ CWAS } & 1 層 & 38.6 & 24.8 & 2814 & 2.99 \\
\cline { 2 - 6 } & 2 層 & 36.4 & 26.7 & 2550 & 2.53 \\
\hline \multirow{2}{*}{ CWBS } & 1 層 & 42.0 & 25.7 & 2587 & 2.99 \\
\cline { 2 - 6 } & 2 層 & 30.6 & 29.5 & 2558 & 2.53 \\
\hline \multirow{2}{*}{ CWAF } & 1 層 & 41.2 & 25.5 & 2457 & 3.03 \\
\cline { 2 - 6 } & 2 層 & 38.6 & 27.6 & 2423 & 2.55 \\
\hline \multirow{2}{*}{ CWBF } & 1 層 & 40.1 & 24.9 & 2765 & 3.03 \\
\cline { 2 - 6 } & 2 層 & 35.9 & 24.8 & 3160 & 2.55 \\
\hline
\end{tabular}

* FRC の引張強度は割裂引張強度試験方法により求めた

表 4 鉄骨および鉄筋の材料特性

\begin{tabular}{c|c||c|c|c}
\hline \multicolumn{2}{c||}{$\begin{array}{c}\text { 種別·使用箇所 } \\
\text { 降伏点 } \\
(\mathrm{MPa})\end{array}$} & $\begin{array}{c}\text { ヤング係数 } \\
(\mathrm{GPa})\end{array}$ & $\begin{array}{c}\text { 引張強度 } \\
(\mathrm{MPa})\end{array}$ \\
\hline \hline $\mathrm{PL}-6(\mathrm{SS} 400)$ & ウェブ & 260 & 190 & 409 \\
\hline $\mathrm{PL}-9(\mathrm{SS} 400)$ & フランジ & 282 & 197 & 418 \\
\hline $\mathrm{PL}-16(\mathrm{SS} 400)$ & 接合部 & 268 & 200 & 427 \\
\hline $\mathrm{D} 6(\mathrm{SD} 295 \mathrm{~A})$ & 壁補強筋 & 345 & 190 & 501 \\
\hline
\end{tabular}



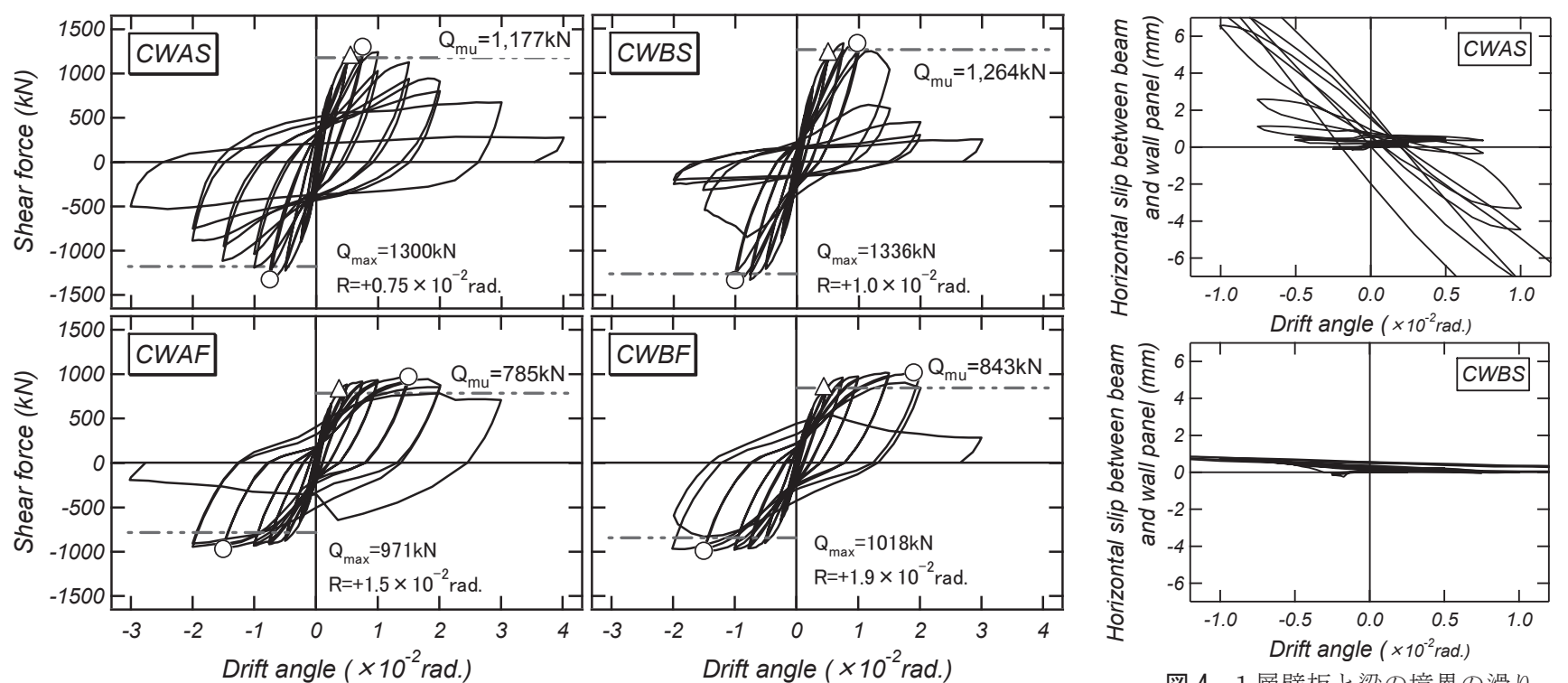

図 4 1 層壁板と梁の境界の滑り

$--Q_{\operatorname{mu}} \circ Q_{\max } \Delta$ Column Flange Yield

図 3 せん断力一部材角関係

部においてコンクリートの圧壞が顕著となったが, 試験体 CWBF で はそれに加えて, 壁板の中央付近でもコンクリートの圧壊の兆候が 観察されており，ここでも破壊性状（損傷箇所）の差異が勒性能に 影響を及ぼしたと考えられる。

以上より, 破壊形式に拘わらず, 壁縦筋の定着を省略しても最大 耐力への影響はほとんどないといえる。さらに, 変形性能に関して は壁縦筋の定着を省略することにより若干ではあるが向上する傾向 にある。

\section{FEM 解析}

本章では 2 章で示した耐震壁の静的載荷実験を対象に非線形FEM 解析を実施する。解析による履歴特性, 破壊状況および変形挙動と 実験結果の比較から CES 耐震壁のモデル化および材料構成則の妥 当性について検討し, 内部応力状態から壁縦筋の定着の有無による 応力伝達メカニズムの差異を明らかにする。なお, 解析には市販の コンクリート構造非線形 FEM 解析ソフト「FINAL」を用いた。

\section{1 解析概要}

解析は 2 次元解析とし, 平面応力場を仮定した。図 5 に要素分割 図を示す。本解析では実験と同様のせん断スパン比 1.1 および 1.65 とするため, 試験体の上スタブから実験における想定加力高さまで 仮想スタブを弾性体で定義し, 仮想スタブ上端に実験と同様の部材 角となるよう強制変位を与えた。軸力は仮想スタブ上端に一定軸力 $1,260 \mathrm{kN}$ を等分布荷重で与えた。解析は変位制御による正負交番繰 返し載荷とした。解析で用いた材料特性は, コンクリートの引張強 度を除いて表 3 および表 4 の值を用いている。なお, 解析は $\mathrm{R}=2.0 \times 10^{-2} \mathrm{rad}$.の第 2 サイクルまでとした。

\section{2 材料モデル}

コンクリートは四辺形平面応力要素を用い, 等価一軸ひずみに基 づく直交異方性モデルにより表現した。ひび割れは要素内に一様に 分布し, 多方向のひび割れが考慮できる非直交ひび割れモデル ${ }^{7} に$ より表現した。また, 壁板のせん断補強筋は埋め込み鉄筋として要 素内に層状置換した。二軸応力下の破壊条件は Kupfer らの提案 ${ }^{8)}$

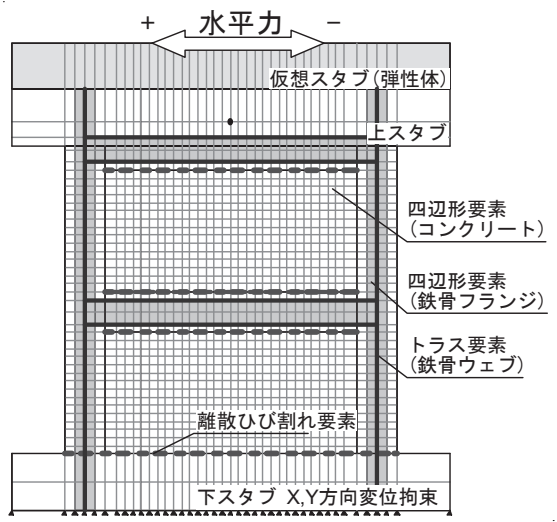

図 5 要素分割図

に従った。応力ーひずみ関係については, 圧縮側の応力上昇域は修 正 Ahmad モデル ${ }^{9)}$ と，軟化域はコンクリートの材料試験を参考に 図 6(a)に示す多折線でモデル化した。引張側はひび割れ発生までを 線形で仮定し，ひび割れ発生後の軟化域は出雲らの提案モデル ${ }^{10)}$ 用いた。柱および梁要素では上記のモデルの係数 $\mathrm{c}=1.0$ としてひび 割れ発生後に引張応力をほとんど負担していないものとし，鉄筋が ある壁板要素では $\mathrm{c}=0.2$ としてテンションスティフニングを考慮し た (図 6(b))。コンクリートの繰り返し応力下における履歴モデルは, 除荷と再載荷過程における軟化挙動を考慮した曲線モデル ${ }^{11)}$ を使用 した（図 6(c)）。ひび割れ後のせん断伝達モデルには図 6(d)に示す Al-Mahaidi モデル ${ }^{12)}(\beta=1.0$ の場合）に対して，せん断伝達剛性が わずかに大きくなるように $\beta=0.8$ として多折線でモデル化した。

また, 文献 13)において RC 構造物の初期ひび割れを考慮した FEM 解析を実施している。その結論としてコンクリートの引張強度の低 減することにより試験結果との整合性の改善が示されている。本論 で解析対象とした試験体においても載荷前に初期ひび割れの発生が 確認されており, 文献 13)を参考に表 3 に示寸 FRC の引張強度を壁 板では $0.37 \mathrm{MPa}$ ，柱および梁では $0.75 \mathrm{MPa}$ と低減することとした。 鉄骨フランジは四辺形平面応力要素でモデル化し，鉄骨ウェブは トラス要素で線材としてモデル化した。鉄骨および鉄筋の繰返し応 力は図 7 に示す Ciampi 等の提案する修正 Menegotto-Pinto モデル ${ }^{14)}$ とした。 
コンクリートと鉄骨間をライン要素で定義し，文献 15)を参考に して付着応力ーすべり関係をモデル化した（図 8)。ここで, 最大付 着応力は $\tau_{\max }=0.1 \sigma_{\mathrm{B}}\left(\sigma_{\mathrm{B}}\right.$ : コンクリート強度 $)$ とし ${ }^{6}$, 鋼材の軸方 向のみすべりが生じるようにモデル化した。

壁縦筋の定着の有無のモデル化に関しては，壁板と梁およびスタ ブの間に離散ひび割れ要素を使用し, 試験体 CWAS および CWAF ではひび割れ後の引張応力が零となるモデルを, 試験体 CWBS およ び CWBF ではひび割れ強度に達したあと鉄筋の抜け出しを考慮す

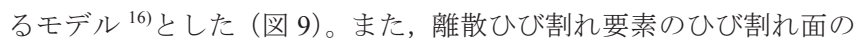
せん断伝達特性を長沼の提案するモデル ${ }^{12)}$ とし, それぞれモデル化 を行った。

\section{4. 解析結果}

\section{1 履歴特性と壁板のずれ}

図 10 に実験と解析における履歴特性の比較を示す。図中には, 実 験結果と同様に解析結果の降伏点と最大耐力点を併せて示している。 また, 図 11 に各変形角 1 サイクル目の正載荷ピーク時の 1 層梁と壁 板のずれを示す。実験における壁板と梁のずれは図 12 に示す 1 層梁 下に取り付けた変位計から求めた。

せん断力ー変形部材角関係において，いずれの試験体も初期剛性 はひび割れ強度を低減させているものの若干大きめの評価となって いることが確認された。また, 実験では $\mathrm{R}=0.5 \times 10^{-2} \mathrm{rad}$. 近傍において 引張側柱の鉄骨フランジの降伏が確認されたが，解析ではそれより 小さい部材角で降伏が見られ，ここでも剛性を若干高めに再現する 傾向が確認された。しかしながら, 全試験体において降伏時のせん 断耐力を比較すると実験結果と良く一致している。最大耐力に関し ても, 最大耐力に達する部材角が異なる試験体も見られるが, 最大 耐力の実験值と解析值は非常に良く一致していることがわかる。

最大耐力以降の耐力低下に関しては, せん断破壊先行型試験体 CWAS では実験と同様に徐々に耐力低下寸る傾向が確認された。一 方, 試験体 CWBS の実験における耐力低下は, $\mathrm{R}=1.5 \times 10^{-2} \mathrm{rad}$.のサイ クルにおいて再現され, 解析における耐力低下は $\mathrm{R}=1.0 \times 10^{-2} \mathrm{rad}$. の 2

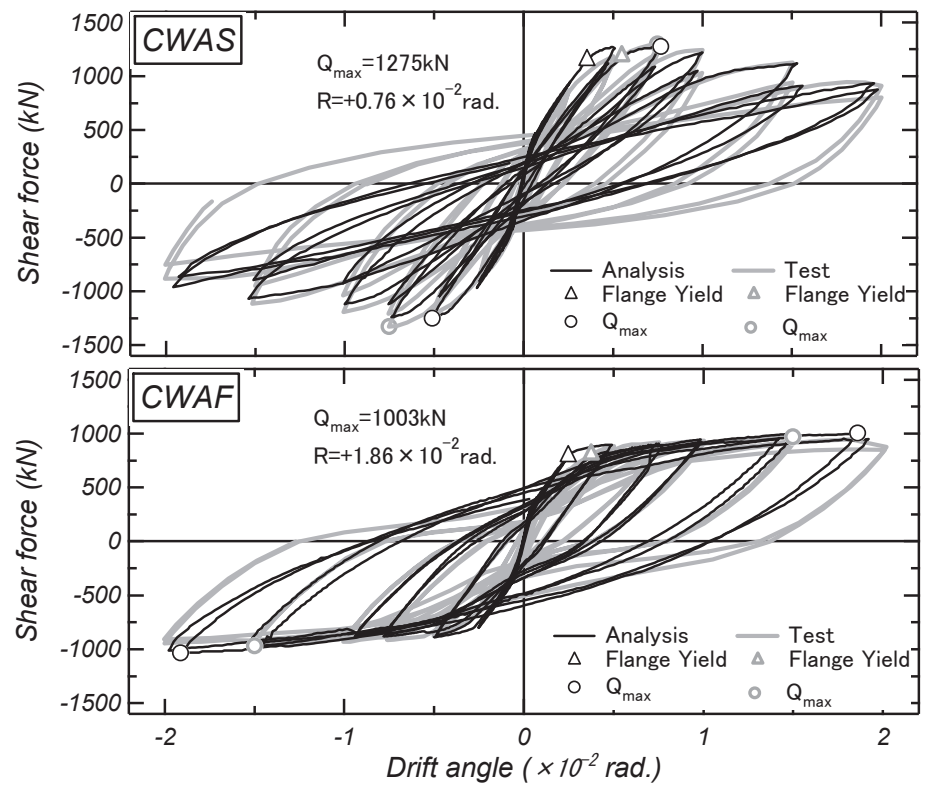

図 10 せん断力一部材角関係の比較

サイクル目において確認された。曲げ降伏先行型試験体 CWAF およ び CWBF の耐力低下に関しては, $\mathrm{R}=2.0 \times 10^{-2} \mathrm{rad}$.のサイクルまで起こ らず，実験結果と一致した。

除荷剛性（履歴性状）については，曲げ降伏型試験体をはじめ実 験結果を精度良く再現できている。ただし, 試験体 CWAS の除荷剛 性は，試験体 CWBS と比べるとやや原点を指向している。

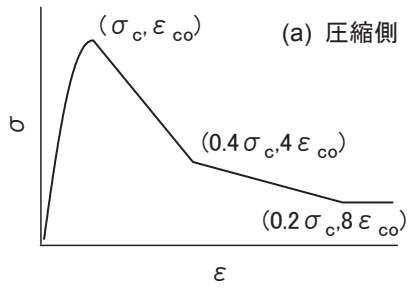

(c) 履歴特性
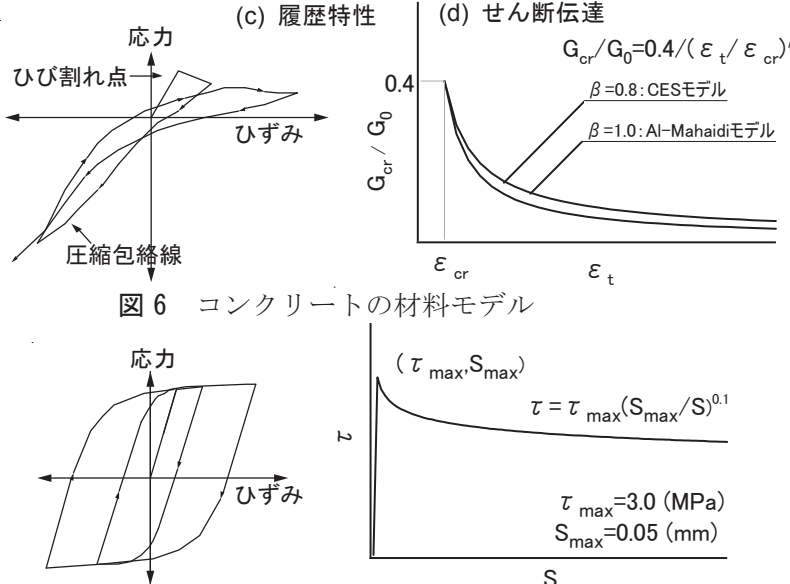

図 7 鋼材の履歴特性

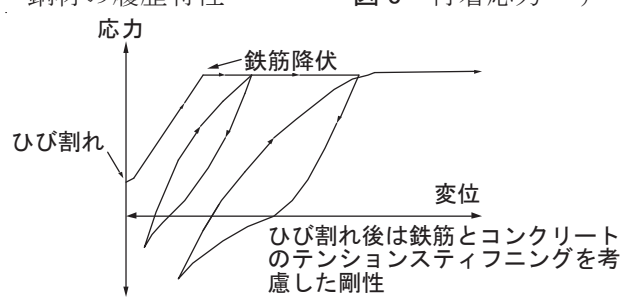

図 9 鉄筋の抜け出し関係

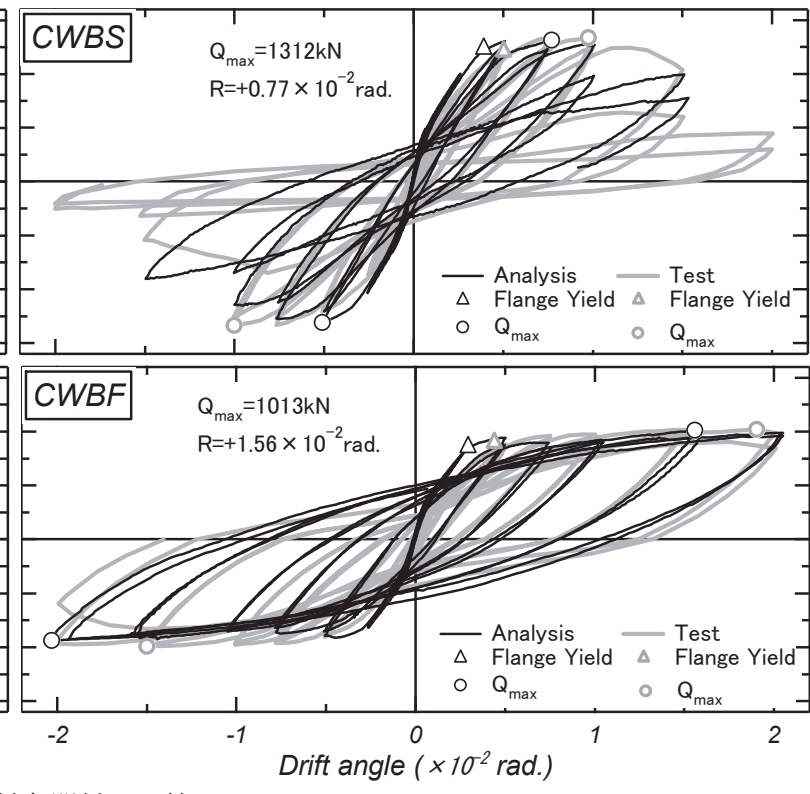

図 8 付着応力ーすべり関係

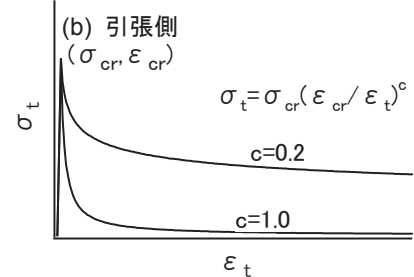

の材料モデル

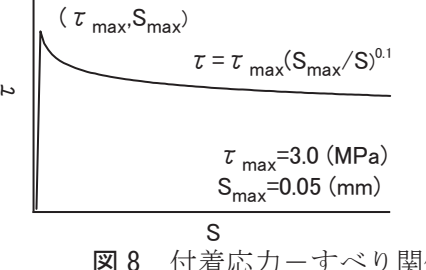

* 
図 11 の 1 層梁下のずれを見ると, 試験体 CWAS の実験結果は $\mathrm{R}=1.0 \times 10^{-2} \mathrm{rad}$.のサイクルから増大が見られ, 解析結果も $\mathrm{R}=0.75 \times 10^{-2} \mathrm{rad}$.のサイクルからずれが増大しており, 1 層梁下で生じ るずれを概ね模擬できている。一方で, 壁縦筋の定着を有する試験 体 CWBS は実験および解析ともにずれはほとんど生じていない。こ のことから, 壁縦筋の定着がないことにより, 梁下の部分でずれを 考慮したモデル化の違いが, 試験体 CWAS の除荷剛性に現れたとい える。なお，曲げ降伏型の試験体 CWAF および CWBF の解析結果 は，ほとんどずれが生じておらず，実験結果と対応している。

以上から大局的に見て, 耐力, 履歴性状ともに実験結果を概称模 擬できたといえる。

\section{2 脚部の変形}

図 13 に $\mathrm{R}=0.5 \times 10^{-2}$ および $0.75 \times 10^{-2} \mathrm{rad}$.の 1 サイクル目の正載荷ピ 一ク時の壁脚部軸方向変形分布を示す。変形は図 12 に示寸 5 箇所の 壁脚部軸方向の変位である。

壁縦筋の定着がある試験体 CWBS では, 載荷サイクルの進行につ れて解析の引張側変形量がやや大きくに評価される結果となったが, 曲げ降伏型の試験体 CWBF では, 逆に引張側壁板の変形量が小さく
評価される結果となった。一方,壁縦筋の定着を省いた試験体 CWAS およびCWAFでは, 全ての変形サイクルにおいて実験での挙動を精 度良く再現されていることが確認された。また，解析において，壁 縦筋の定着のない試験体 CWAS および CWAF の引張側変形量は壁 縦筋の定着のある試験体 CWBS および CWBF と比べて大きく, 壁 縦筋の定着のモデル化の違いによる影響が認められる。しかしなが ら, 図 10 に示すせん断力一部材角関係の $\mathrm{R}=0.75 \times 10^{-2} \mathrm{rad}$.までのサイ クルを見ると壁縦筋の定着の有無の影響は顕著には認められず，耐 荷性能に及ぼす壁縦筋のモデル化の違いの影響は小さいと考えられ る。

\section{3 変形成分}

図 14 に $\mathrm{R}=1.0 \times 10^{-2} \mathrm{rad}$.までの実験と解析におけるせん断力一せん

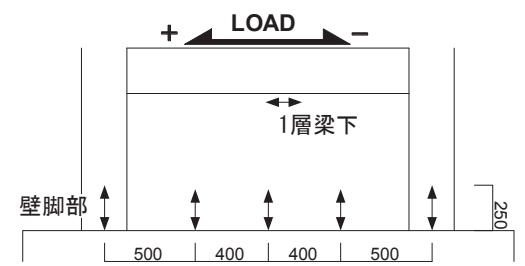

図 12 変位計測位置

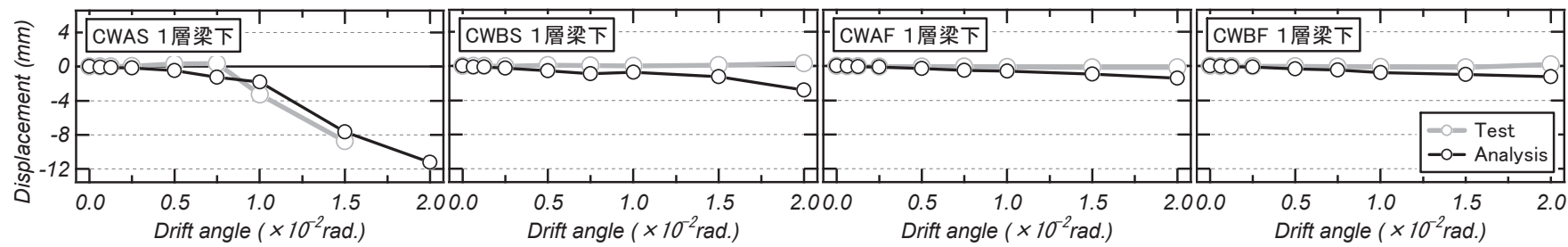

図 11 解析と実験における梁と壁板のずれ

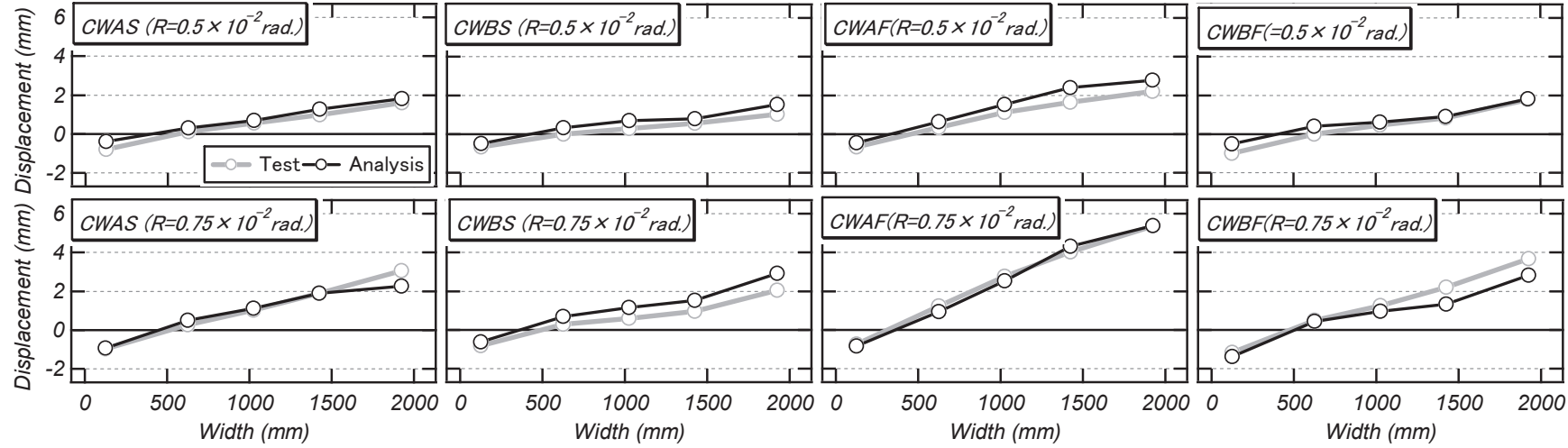
図 13 脚部軸方向変形分布

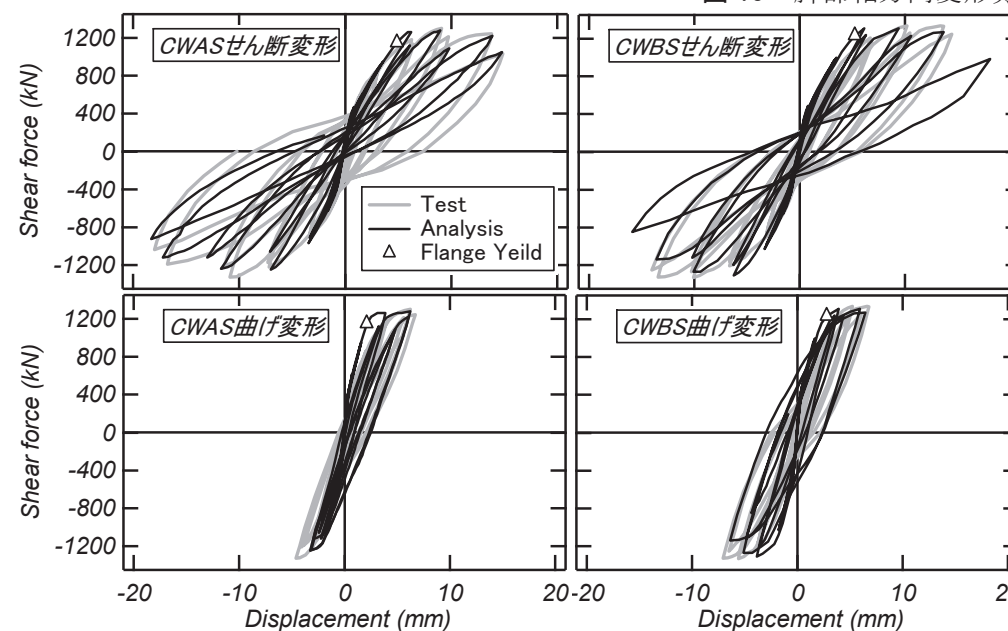

図 14 実験と解析における変形成分の比較 $\left(\mathrm{R}=1.0 \times 10^{-2} \mathrm{rad}\right.$.まで $)$

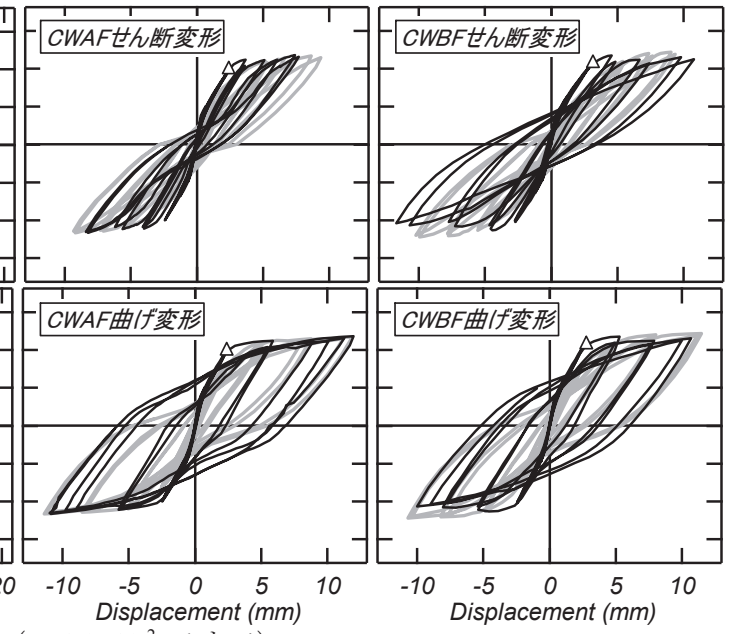




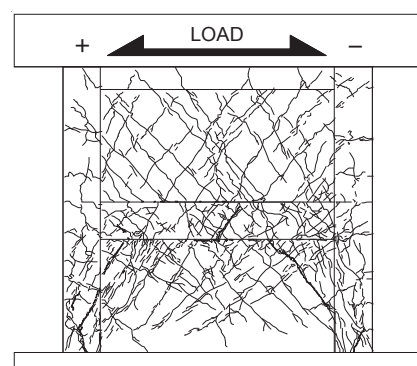

試験体CWAS

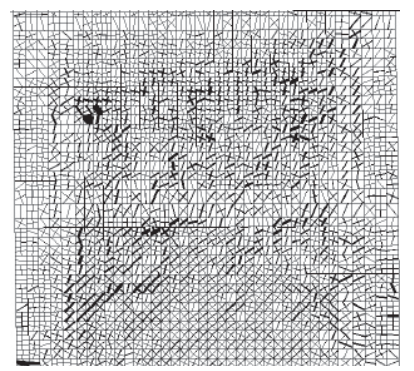

(a) CWAS
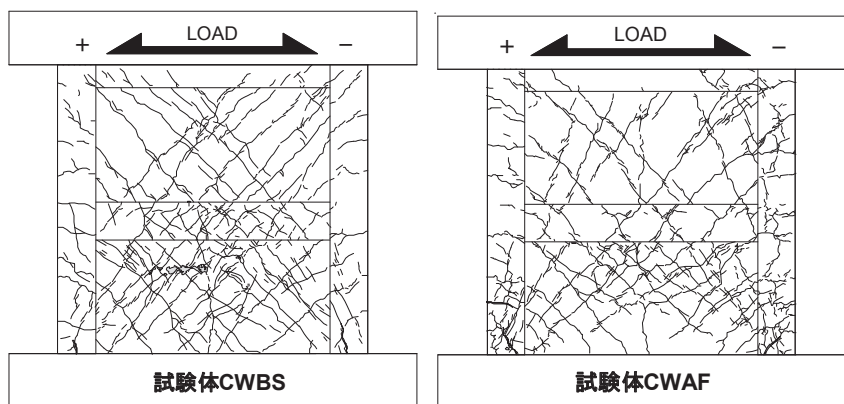

図 15 試験体破壊状況 $\left(\mathrm{R}=1.0 \times 10^{-2} \mathrm{rad}.\right)$

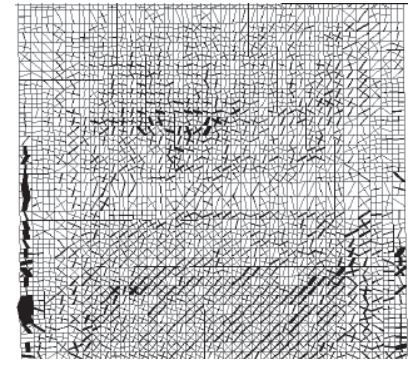

(b) CWBS

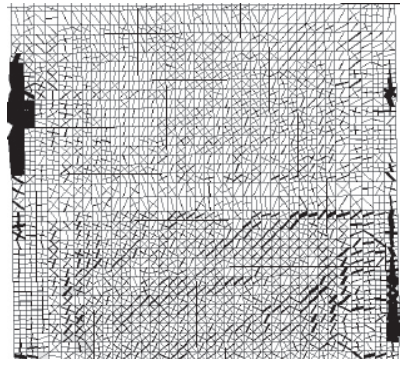

(c) CWAF

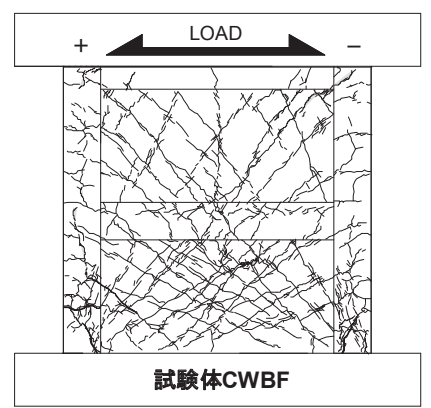

試験体CWBF

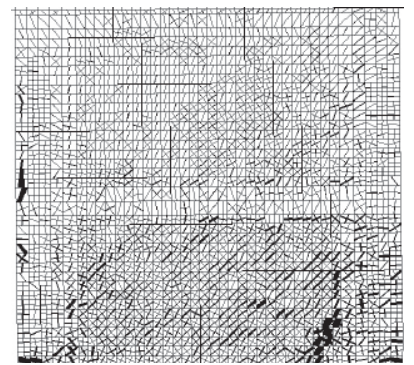

(d) $\mathrm{CWBF}$

図 16 解析における損傷状況 $\left(\mathrm{R}=1.0 \times 10^{-2} \mathrm{rad}\right.$.

断変形成分および曲げ変形成分の履歴特性のそれぞれの比較を示す。 実験および解析の曲げ変形は高さ方向に 7 分割して測定した側柱の 軸方向変形量から求め, せん断変形は全体の変形から曲げ変形を差 し引いたものである。

せん断破壊先行型の試験体 CWAS および CWBS は, せん断変形 が曲げ変形より大きく, 曲げ降伏先行型の試験体 CWAF および CWBF は, 曲げ変形がせん断変形より大きくなっており, 全体的な 傾向は捉えられている。また, せん断力一せん断変形の履歴特性は, ややスリップ型, せん断力ー曲げ変形の履歴形状は紡錘型となって おり，これも概ね表現できている。

せん断破壊先行型試験体では, 試験体 CWBS の $\mathrm{R}=1.0 \times 10^{-2} \mathrm{rad}$. の 2 サイクル目 (最大変形時) において, 解析におけるせん断変形成 分が実験結果と比べて大きくなっているが, 解析における挙動と実 験の挙動が概放一致している。また, 載荷サイクルの進行に伴い試 験体 CWAS の除荷時の剛性が実験と異なり小さくなる傾向を示し ているが, これは, 図 10 と同様の傾向である。つまり, せん断力ー せん断変形の原点指向型の特性の影響が, 図 10 のせん断力一部材角 関係に現れたことがわかる。

試験体 CWAS のせん断変形を除く全ての解析結果において, 降伏 時近傍までの剛性が大きい。特に曲げ変形において, 曲げ降伏まで の剛性を大きめに評価する結果となっている。これも, 図 10 のせん 断力一部材角の関係において, 解析での剛性が若干大きい傾向が同 じように現れている。

\section{4 損傷状況}

$\mathrm{R}=1.0 \times 10^{-2} \mathrm{rad}$.における実験および解析における損傷状況を図 15 および図 16 にそれぞれ示す。また, 図 16 の要素の塗りつぶし箇所 は要素のひび割れ幅を現しており,ひび割れ幅は 10 倍に拡大してい る。従って, 要素の塗りつぶしは, コンクリートの圧壊を示すもの ではない。

せん断破壊先行型試験体 CWAS では，1 層壁板脚部および中央部
と比較して 1 層壁板上隅角部に損傷の集中していることが確認でき る。逆に試験体 CWBS では，上隅角部の損傷は少なく，1層壁板の 全体的に損傷が確認され，解析においても試験体 CWAS との損傷状 沉の違いが認められた。両試験体ともに解析と実験における損傷の 集中箇所が概ね一致する結果となった。

曲げ降伏先行型試験体では，2つの試験体の破壊状況の違いが明 確に現れているわけではないが，1層側柱の近傍に損傷の集中が認 められ，曲げせん断ひび割れによる損傷も現れており，全体的に実 験における損傷状況と一致していることが伺える。

以上より, 本解析モデルにより履歴特性, 破壊性状, 脚部軸方向 変形および梁と壁板のずれに関して, 実験結果を概数良好に再現で きているといえる。

\section{5. 内部応力状態}

\section{1 最小主応力}

図 17 に $\mathrm{R}=0.75 \times 10^{-2} \mathrm{rad}$.の正載荷 1 サイクル目ピーク時における耐 震壁の最小主応力分布（圧縮応力分布）を示す。

破壊モードに拘わらず，すべての試験体において，1 層から 2 層 にかけて壁板に斜め圧縮ストラットが形成されており，圧縮側の壁 板隅角部や側柱脚部に高い圧縮応力が生じている。一方, 形成され た圧縮ストラットの幅は，せん断破壊先行型試験体の方が曲げ降伏 先行型試験体のものと比べて大きくなる傾向が認められる。しかし ながら，破壊モードに拘わらず壁縦筋の定着の有無が圧縮ストラッ トの形状に及ぼす影響は顕著に認められない。これは, 図 11 に示し たように $\mathrm{R}=0.75 \times 10^{-2} \mathrm{rad}$.までは壁板と梁のずれが小さいことに起 因しているものと考えられる。

\section{2 負担せん断力}

図 18 に各試験体の負担せん断力の推移を示す。負担せん断力は, 壁板，圧縮側柱コンクリート，圧縮柱内鉄骨および引張柱内鉄骨に 分けて示している。また，図 19 に示される 3 つの高さ $(\mathrm{h}=0,375$ 


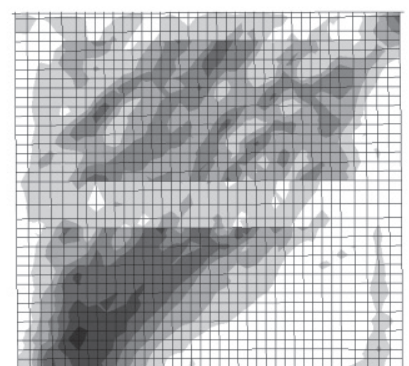

(a) CWAS

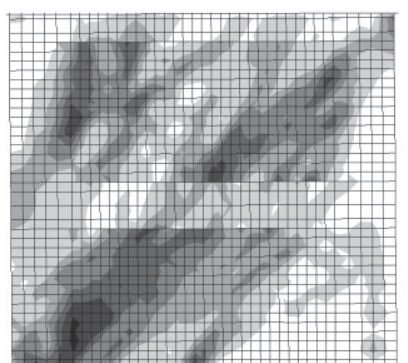

(b) CWBS

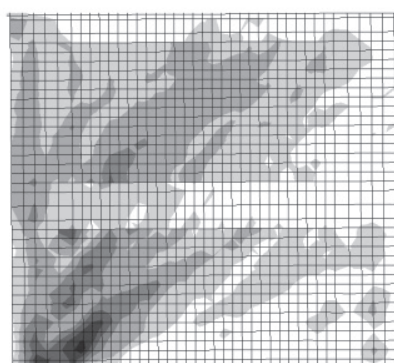

(c) CWAF

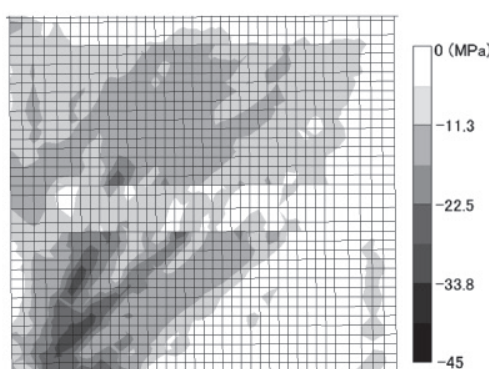

(d) CWBF

図 17 最小主応力分布 $\left(\mathrm{R}=0.75 \times 10^{-2} \mathrm{rad}.\right)$

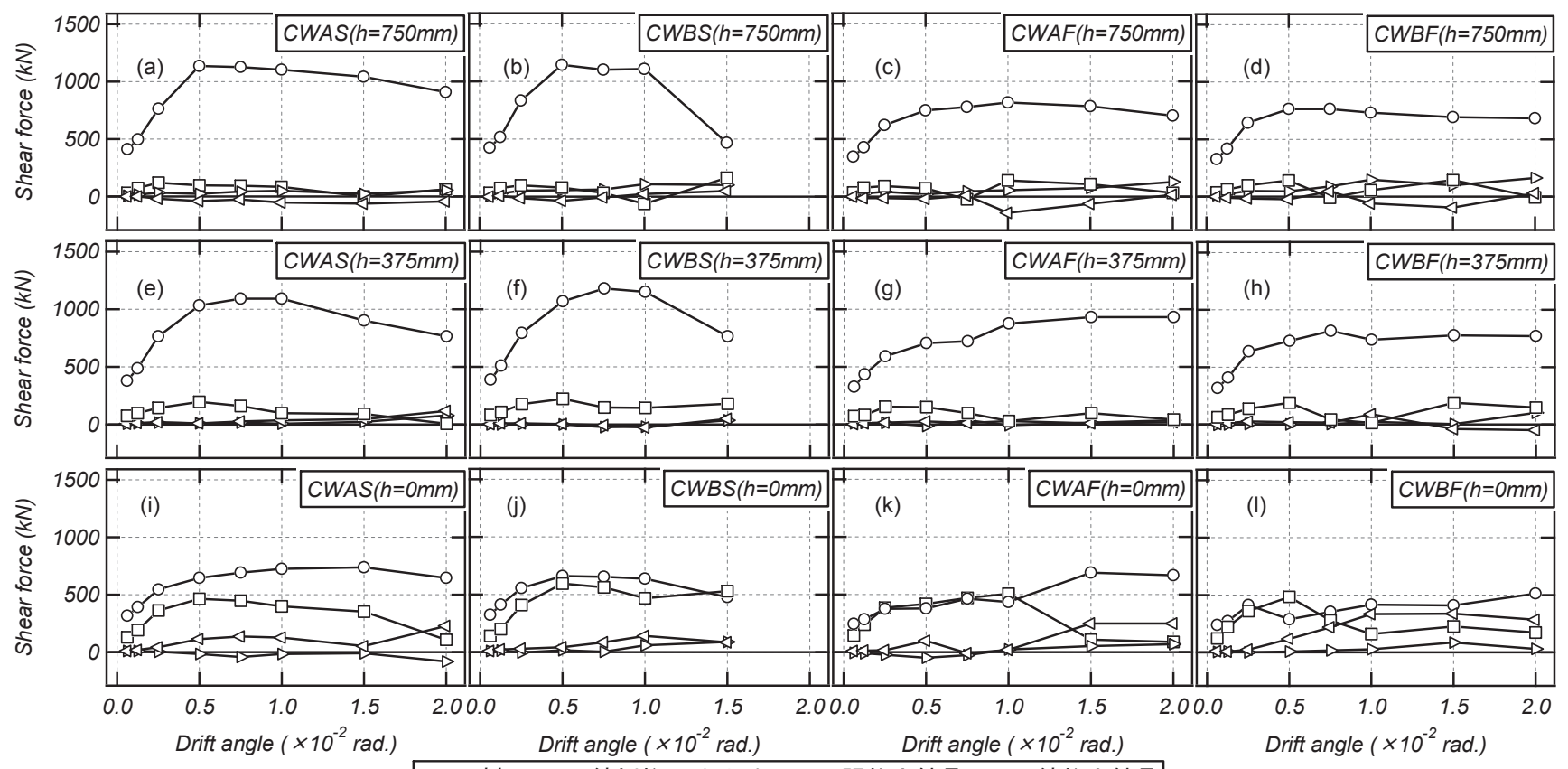

図 19 負担せん断力推移

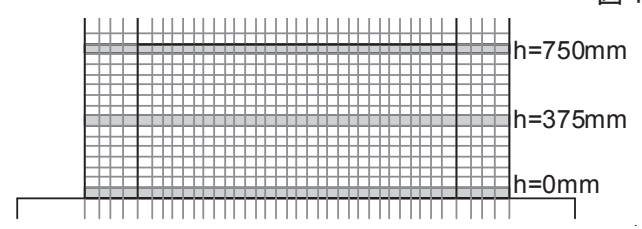

図 18 コンクリートの要素位置

および 750mm）における結果についてそれぞれ示している。

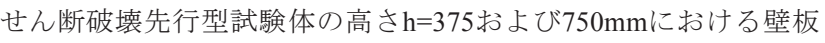
の負担せん断力に着目すると, 定着のない試験体CWASでは, $\mathrm{R}=0.75 \times 10^{-2} \mathrm{rad}$.以降の載荷サイクルから, 徐々に低下しているが（図

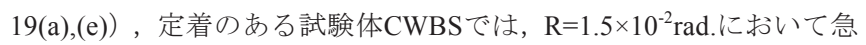
激な低下が生じている（図19(b),(f)）。これは, 図10に示す試験体の せん断力ー部材角関係の耐力低下状況および図16に示す試験体の損 傷状況と対応している。すなわち，定着のない試験体CWASでは， 壁板の中央から上部にかけてのコンクリートの損傷が軽減され, 耐 力が徐々に低下したと考えられる。一方, 定着のある試験体CWBS では, 壁板の中央から上部にコンクリートの損傷が集中し, 耐力が 急激に低下したと考えられる。一方, 曲げ降伏先行型試験体CWAF およびCWBFでは, 壁板の負担せん断力の急激な低下は認められな い(図19(c),(d),(g),(h))。

次にせん断破壊先行型試験体の高さ $\mathrm{h}=0 \mathrm{~mm}$ に着目すると, 試験体
CWBSにおける圧縮側柱の負担せん断力は，試験体CWASのものと 比べて全体的に大きくなる傾向が見てとれる（図19(i),(j)）。一方， 曲げ降伏先行型試験体CWAFおよびCWBFでは, $\mathrm{R}=0.25 \times 10^{-2} \mathrm{rad}$.の載 荷サイクルまで圧縮側柱および壁板の負担せん断力の推移状況に明

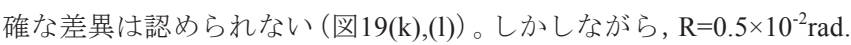
以降の載荷サイクルに着目すると, 定着のない試験体CWAFでは, 圧縮側柱コンクリートの負担せん断力は $\mathrm{R}=1.5 \times 10^{-2} \mathrm{rad}$.の載荷サイ クルで低下が生じているのに対し, 試験体 CWBFでは, $\mathrm{R}=0.75 \times 10^{-2} \mathrm{rad}$ から低下が生じている。また，両試験体の圧縮側柱 鉄骨のせん断力は圧縮側柱コンクリートのせん断力の低下に伴い増 加する傾向が認められ，圧縮側柱の負担せん断力はコンクリートか ら鉄骨に移っていることが認められる。両試験体とも $\mathrm{R}=2.0 \times 10^{-2} \mathrm{rad}$. では, 壁板, 圧縮柱鉄骨および圧縮側柱コンクリートの負担せん断 力の割合は違うものの, 全ての部材の負担せん断力の合計は同程度 であり（図10），両試験体の破壊モードは同様のものであることが 考えられる。

\section{3 せん断応力分布}

図 20 に $\mathrm{R}=0.5 \times 10^{-2}$ およびほぼ最大耐力に達した $\mathrm{R}=0.75 \times 10^{-2} \mathrm{rad}$. の 1 サイクル目の正載荷ピーク時の耐震壁の平均せん断応力度の分 布を示す。同図の縦方向実線は側柱位置を示している。平均せん断 応力度は図 18 に示される位置 (網掛け内) におけるコンクリート要 


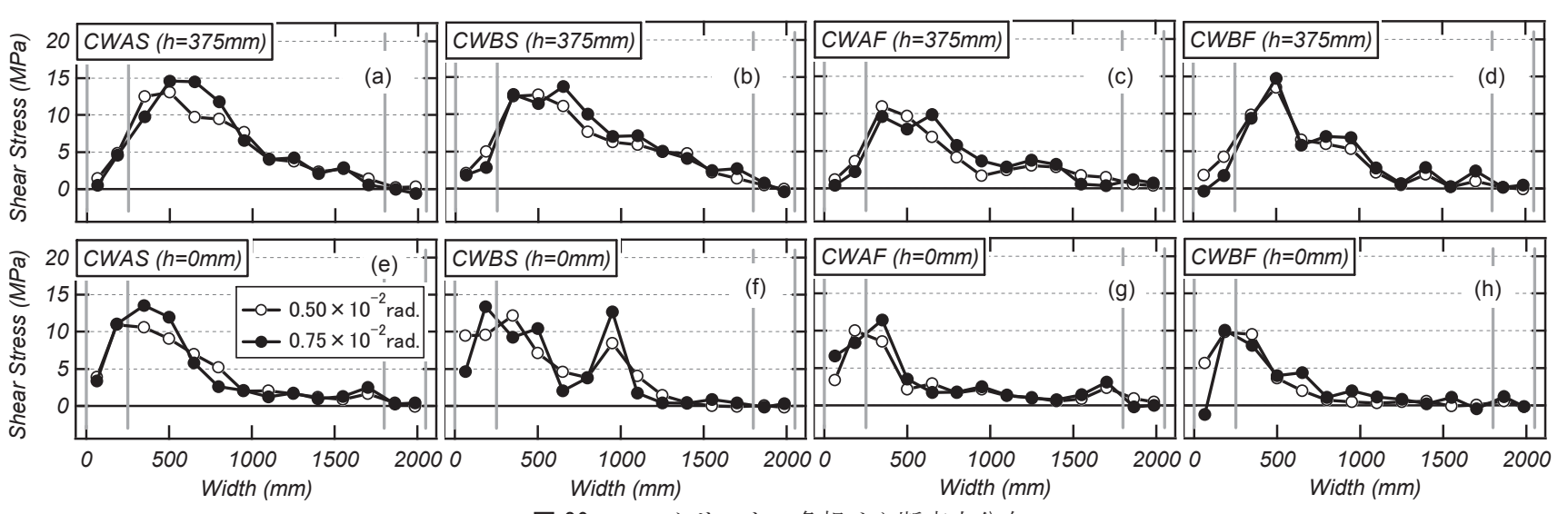

図 20 コンクリートの負担せん断応力分布

素に生じるせん断力を用いて, 側柱は要素 2 個分, 壁板は 3 個分の せん断力の合計を断面積で除して平均化した值である。

高さ $\mathrm{h}=0 \mathrm{~mm}$ では, いずれの試験体においても圧縮側柱および壁 板の圧縮側のコンクリートでせん断応力度の大部分を負担している ことがわかる。高さ $\mathrm{h}=375 \mathrm{~mm}$ では, 高さ $\mathrm{h}=0 \mathrm{~mm}$ と比べて圧縮側柱 のせん断応力度が減少し, 壁板の圧縮側のせん断応力度が増加して いる（例えば，図 20(a),(e))。以上のようなことが確認できるが, 壁 縦筋の定着がある試験体とない試験体の間では, 最大耐力付近にお いて壁板のせん断応力度の分布に特筆すべき違いは認められなかっ た。したがって, 今回の実験の範囲では, CES 耐震壁の耐荷性能に 及ぼす定着の有無の影響は小さいと考えられる。

\section{6. まとめ}

本論では, CES 合成構造の連層耐震壁の 2 次元非線形 FEM 解析 を実施し, 解析モデルの妥当性および壁縦筋の有無による応力伝達 メカニズムの差異についての検討を行った。

本研究により得られた知見を以下に示す。

1)破壊形式に拘わらず, 壁縦筋の定着を省略しても, CES 造耐 震壁の最大耐力へ及ぼす影響はほとんどない。さらに, 変形 性能に関しては壁縦筋の定着を省略することにより若干では あるが向上する傾向にある。

2) 本論に示寸解析モデルおよび材料構成則によって, CES 造耐 震壁の復元力特性, 破壊性状, 脚部変形性状および梁と壁板 のずれなどの挙動を精度よく再現できた。

3) せん断破壞先行型試験体の最大耐力時の壁板に形成される圧 縮ストラットでは, 壁板の下隅角部から上部にかけて高い応 力が発生しており, 各試験体の実験における損傷状況と対応 していることが確認された。

4) せん断破壞先行型試験体では, 壁縦筋の定着のある試験体は 定着のない試験体と比べて壁板の負担せん断力が早く低下し ており, 定着の有無によって, 壁板の中央および上部の負担 せん断力に差異が認められた。

5）曲げ降伏先行型試験体では, 圧縮側柱の負担せん断力はコン クリートから鉄骨に移行していることが認められ, その傾向 は定着のある試験体の方が定着のない試験体と比べて早期に 生じている。

6) せん断破壊先行および曲げ降伏先行型試験体の最大耐力時の
壁板の圧縮ストラットおよびせん断応力度分布では，壁縦筋 の定着の有無の影響はほとんど認められず，内部応力状態か らも CES 耐震壁の耐荷性能に及ぼす定着の有無の影響は小さ いと考えられる。

\section{参考文献}

1) 田口孝, 永田諭, 松井智哉, 倉本洋 : H 型鉄骨を内蔵した CES 柱の構造 特性，コンクリート工学年次論文集，Vol.28，No.2， pp.1273-1278，2006.7

2) 永田諭, 松井智哉, 倉本洋: 鉄骨コンクリート造柱梁接合部の構造性能 に関する基礎研究，コンクリート工学年次論文集，Vol.28，No.2, pp.1267-1272, 2006.7

3) 倉本洋, 松井智哉, 今村岳大, 田口孝: CES 合成構造平面架構の構造性 能, 日本建築学会構造系論文集, No.629, pp.1103-1110, 2008.7

4) 春山智史, 小野里憲一, 戸澤知仁 : 鉄骨鉄筋コンクリート造耐震壁の定 着方法に関する研究, 日本建築学会大会学術講演梗概集, C-1, pp. $1147-1148,2006.9$

5) 鈴木卓, 松井智哉, 倉本洋 : CES 造耐震壁の構造性能に及ぼす壁縦筋の 定着状態の影響, コンクリート工学年次論文集,Vol.32, No.2, pp.1189-1194, 2010.7

6) 日本建築学会 : 鉄骨鉄筋コンクリート構造計算規準・同解説，2001

7) 長沼一洋, 栗本修, 江戸宏彰 : 鉄筋コンクリート壁体の FEM による正負 繰り返し及び動的解析, 日本建築学会構造系論文集, 第 544 号, pp.125-132, 2001.6

8) Kupfer, H.B, Gerstle, K.H. : Behavior of Concrete under Biaxial Stress, Journal of the Engineering Mechanics Division, Vol.99, No.EM4, pp.853-866, 1973.8.

9）長沼一洋：三軸圧縮応力下のコンクリートの応力〜ひずみ関係, 日本建 築学会構造系論文集, 第 474 号, pp.163-170, 1995.8

10) 出雲淳一, 島弘, 岡村甫 : 面内力を受ける鉄筋コンクリート板要素の解 析モデル, コンクリート工学, Vol.25, No.9, pp.134-147, 1987.

11）長沼一洋, 大久保雅章 : 繰返し応力下における鉄筋コンクリート板の解 析モデル, 日本建築学会構造系論文集, 第 536 号, pp135-142, 2000.10

12）長沼一洋, 平面応力場における鉄筋コンクリート板の解析モデル, 日本 建築学会構造系論文報告集, 第 421 号, pp.39-48, 1991.3

13) 井本勝慶, 米澤健次, 加藤朝郎, 川里健 : $1 / 4 \mathrm{PCCV}$ の耐圧限界挙動に関 するラウンドロビン解析, コンクリート工学, Vol.41, No.1, pp.153-157, 2003.1

14) Ciampi, V et al : Analysis model for Concrete Anchorages of Reinforcing Bars Under Generalized Excitations, Report No. UCB/EERC-82-83, Univ. of California, Berkeley, 1982.11

15) 後藤康明, 穴吹拓也, 城攻: SRC 造内柱梁接合部におけるせん断応力分 担に関する非線形有限要素解析, 日本建築学会大会学術講演梗概集, C-1, pp.1089-1090, 2005.9

16）三島徹也,山田一宇,前川宏一: 正負交番載荷下における鉄筋コンクリート ひびわれ面の局所的挙動, 土木学会論文, No.442, V-16, pp.161-170, 1992. 